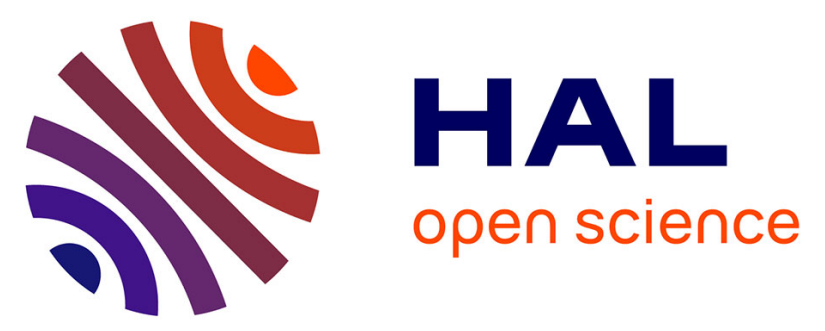

\title{
Contribution to the Identification of the Professional Skills Profile for Coaches in the Algerian Sport Judo System
}

\author{
Jacques Gleyse, Belkadi Adel, Benbernou Othman, Sebbane Mohamed, \\ Laroua Abdelhafid, Bensabeur Mohamed, Jaques Gleyse
}

\section{To cite this version:}

Jacques Gleyse, Belkadi Adel, Benbernou Othman, Sebbane Mohamed, Laroua Abdelhafid, et al.. Contribution to the Identification of the Professional Skills Profile for Coaches in the Algerian Sport Judo System. European Journal of Physical Education and Sport Science , 2015, 8 (2), pp.80-89. 10.13187/ejpe.2015.8.80 . hal-02078205

\section{HAL Id: hal-02078205 https://hal.science/hal-02078205}

Submitted on 1 Sep 2021

HAL is a multi-disciplinary open access archive for the deposit and dissemination of scientific research documents, whether they are published or not. The documents may come from teaching and research institutions in France or abroad, or from public or private research centers.
L'archive ouverte pluridisciplinaire HAL, est destinée au dépôt et à la diffusion de documents scientifiques de niveau recherche, publiés ou non, émanant des établissements d'enseignement et de recherche français ou étrangers, des laboratoires publics ou privés.

\section{(1)(1) $\$(0)$}

Distributed under a Creative Commons Attribution - NonCommercial - ShareAlikel 4.0 
Copyright (C) 2015 by Academic Publishing House Researcher

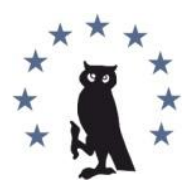

Published in the Russian Federation

European Journal of Physical Education and Sport

Has been issued since 2013 .

ISSN: 2310-0133

Vol. 8, Is. 2, pp. 80-89, 2015

DOI: 10.13187/ejpe.2015.8.80

www.ejournal7.com

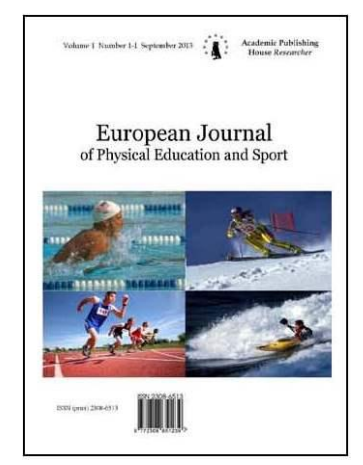

\title{
Articles and Statements
}

UDC 79

\section{Contribution to the Identification of the Professional Skills Profile for Coaches in the Algerian Sport Judo System}

\author{
${ }^{1}$ Belkadi Adel \\ 2 Benbernou Othman \\ 3 Sebbane Mohamed \\ 4 Laroua Abdelhafid \\ 5 Bensabeur Mohamed \\ ${ }^{6}$ Jaques Gleyse
}

${ }^{1}$ Research Laboratory Optimization of Programs in Physical and Sporting Activity-Institute of Physical Education and Sport University of Mostaganem Algeria, Algeria

PhD doctoral degree student

E-mail: adel.belkadi@gmail.com

${ }^{2}$ Research Laboratory Optimization of Programs in Physical and Sporting Activity-Institute of Physical Education and Sport University of Mostaganem Algeria, Algeria

Teacher University, professor

E-mail: benbernouothmane@yahoo.fr

3 Research Laboratory Optimization of Programs in Physical and Sporting Activity-Institute of Physical Education and Sport University of Mostaganem Algeria, Algeria

Teacher University, professor

sebbane2006@yahoo.fr

4 Research Laboratory Optimization of Programs in Physical and Sporting Activity-Institute of Physical Education and Sport University of Mostaganem Algeria, Algeria

PhD doctoral degree student

E-mail: larouaeps@yahoo.fr

5 Research Laboratory Optimization of Programs in Physical and Sporting Activity-Institute of Physical Education and Sport University of Mostaganem Algeria, Algeria

PhD doctoral degree student

E-mail: bp310mostaganem@hotmail.fr

${ }^{6}$ Interdisciplinary Laboratory of Research in Teaching, Education and Training (LIRDEF), France

Teacher University, professor

E-mail: jacques.gleyse@orange.fr

\section{Abstract}

This study was designed to determine The professional skills of Coaches which are identified and judged on a large number of factors (Belkadi, Benbernou, \& Gleyses, 2014). The purpose of this article is to describe the views of the four different professionals actors on coach skills; athletes, coaches, leaders and experts from the Algerian judo sport system, all the actors of that system have 
responded to the same series of questions regarding coaches skills. Across the five groups of specific professional skills, the views expressed are more similar than dissimilar, with each professional emphasizing a different item of the coaches' skills.

The information presented aligns both with and shows that, coaches and athletes have the same representations of technical and teaching skills. However, a discrepancy of representations regarding the organizational and managerial skills. Stakeholder views are compared to the coaching science literature and recommendations to develop a professional skills repository of the judo coach are provided.

Keywords: identification, professional skills, profile, coaches.

\section{Introduction}

If a coach, involved in high-level sport, is admitted to have (or should have) high skills, the nature of these skills must be specified, exactly as the conditions which favor their acquisition (Zarifian, 1995). They do not seem to be simple and thus raise questions, especially in view of the implementation of the training of coaches and transmission of their knowledge.

In fact, so many "very good" current coaches (recognized to be experts by their peers) did initially no training priori intending them to these functions. For this purpose, Ragni (1996) noted (The same phenomenon in athletics, more than half of high level coaches do not have B.E.E.S); For this author (in the expertise of coaches, something escapes the guarantee conferred by the possession of knowledge or qualifications), Indeed in interviews to establish a record of the Olympic experience coaches of different sports disciplines in 2012, Most of them emphasize their experience (of athlete), their knowledge of the environment, a teaching that is primarily realized in the training action, rather than through theoretical knowledge from books. The recruitment of the Olympic teams coaches (the highest level of sports competition), is carried out without being taken into account decisively a level of training certified by a recognized certification in this field.

Theoretical models of training processes (Bruant $(G), 1989$ ) (based on scientific and technical rationalization of the training); And the approach of the coach, addressed in training or presented in books (Weineck 1990; revues Helal, 1986); Dealing with sports training, are generally perceived by the coaches as being out of touch with their practice and inadequate party to organize their work. This seems also not to be limited to the training of Algerian coaches. Indeed, in an article on the expert knowledge structure coaches, Salmela (1994) reported an American research shows that only $46 \%$ of the coaches think that there are weak principles, theories and designs in Judo field. In addition, he says that the training of trainers (coaching classes) and books on training (coaching books) are part of the resources deemed less important by the coaches (Salmela, 1994). Sports coaches who work with high-level athletes are often considered "professional" experts in sport milieu. Commonly, we credit them with high skills in very varied registers (Danvers, 1992). They are presented by many authors as "engineers" of performance (Helal, 1986; Platonov, 1988 Weineck, 1990), as educators, pedagogues (Piéron, 1992), psychologists (Partington, 1988), the managers (Bosc, B1986) etc.

The problem of our present study, constructs the notion of professional competence mainly in reference to the executives of the educational literature, especially (Mialaret 1979 Cardinet 1988 Gillet 1991). These skills are analyzed in two distinct dimensions:

1 / specific skills that allow "Within a family of situations identifying a task problem and its resolution by an effective action (performance" (Gillet, 1991).

2 / classes of business situations that characterize the families of tasks which are related to the functions of their coach. The skills are distinguished as well as and knowledge that stands behind them. (Malglaive 1990; Delbos \& Jorion, 1998; Levy Leboyer, 1997).

\section{Methods and Means: \\ Participants}

This study is realized during the sporting season 2014-2015, The people who voluntarily took part in this study consist of 330 subjects, (225Athletes, 45Coaches, 35Leadershipand 25 experts from the judo field) divided as follows (see Table1, the constitution of the population of the research). 


\section{Materials and Procedure}

\section{The questionnaire}

An analytical model of coaches' skills, articulating five groups of specific skills, and four groups of professional situations classes (technical, educational, relational of organizer and manager "managerial). With several items per classes of professional situations (design and preparation of the training, Conduct of trainings (and track competitions), Organization and management, Institutional and relationship situations.

The questionnaire was administered via the Internet (online). The survey collected, A total of 205 (approximately $62.12 \%$ of responses) of the 330 (100 \%) usable questionnaires from a statistical point of view.

The analysis model, briefly presented above, was the basis for the construction of a survey questionnaire, which combined closed questions, preceded for a quantitative treatment of responses, and spaces as free comment optional, for a possible future qualitative exploitation.

\section{Statistical Analysis}

The coding scheme is designed to facilitate data entry using the SPSS (Statistical Package for the Social Sciences) Version 22. The study of responses differences between groups was performed using the Chi- squared Test.

\section{Results}

The results of the quantitative analysis globally accredit the two advanced hypotheses. Yet, with regard to the first, the weakness of certain staffing prompts us to observe an extreme caution: we claim to identify only trends, which emphasize and strengthen the initial hypothesis.

\section{Specific skills}

Analysis of choice and non choice skills / coach profile:

Technical. Skills

Item A: Amount the training at the optimum level for athletes.

Item C: Being an expert in the knowledge of the competition

\section{Teaching. Skills}

Item D: Be a good teacher, able to facilitate engaging training sessions to explain and convey clearly his analyzes.

Item F: Get involved effectively with each athlete during the trainings.

Relational. Skills

Item B: having a strong personal investment in his work(Get involved without mattering).

Item E: having psychologist qualities, allow the athlete to confide his personal problems.

Organizer and Manager. Skills

Item G: be strict and effective organizer, logistically, on trainings and travel.

Item I: be a good manager of the team's funds.

\section{Managerial, Animation and managing a team. Skills:}

Item $\mathrm{H}$ : represent and defend the interests of the team and discipline in federal bodies.

Item J: ability to discuss with athletes the choices and the important decisions concerning the operation of the team.

\section{Discussions}

Below are expressed in percentages of observed frequencies after grouping responses from various categories of stakeholders on the modalities 15 (choice) on one hand, and non response (non choice) on the other hand. 
The choice of skills in the constitution of the coach's profile:

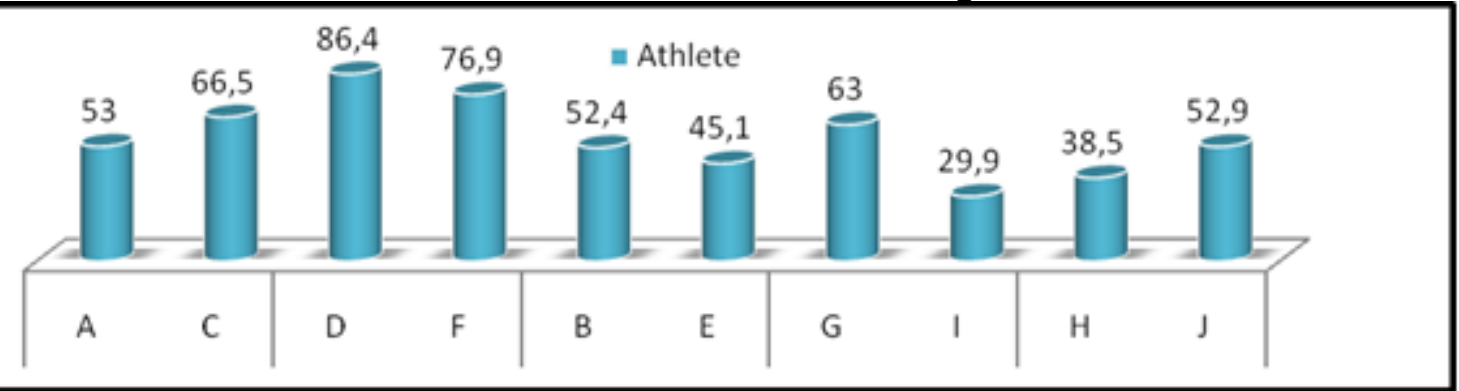

Figure 1: Results of the selection of skills in building the profile of the coach from Athletes

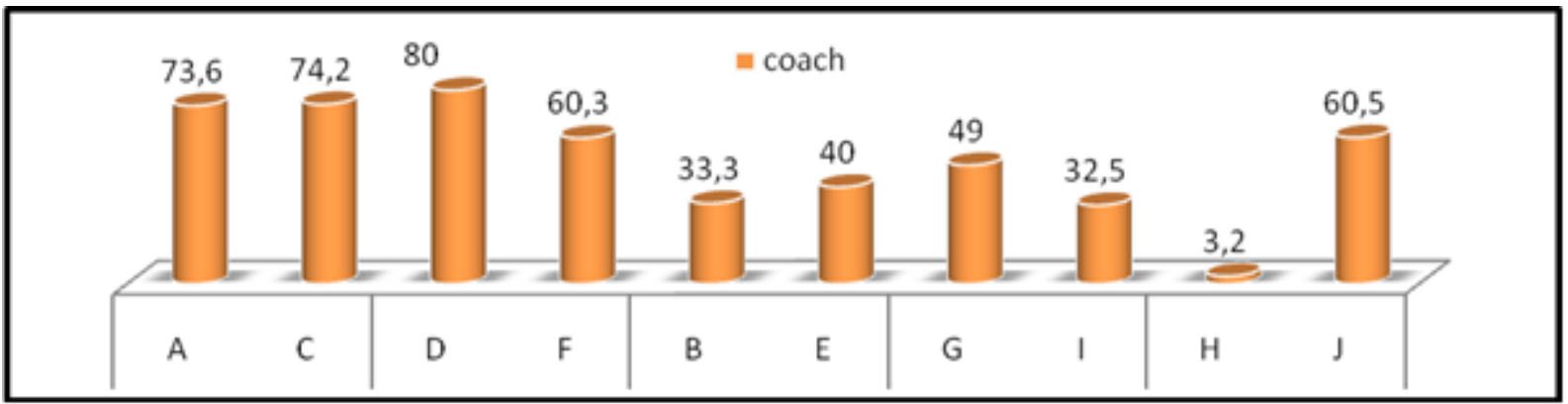

Figure 2: Results of the selection of skills in building the profile of the coach from the coaches.

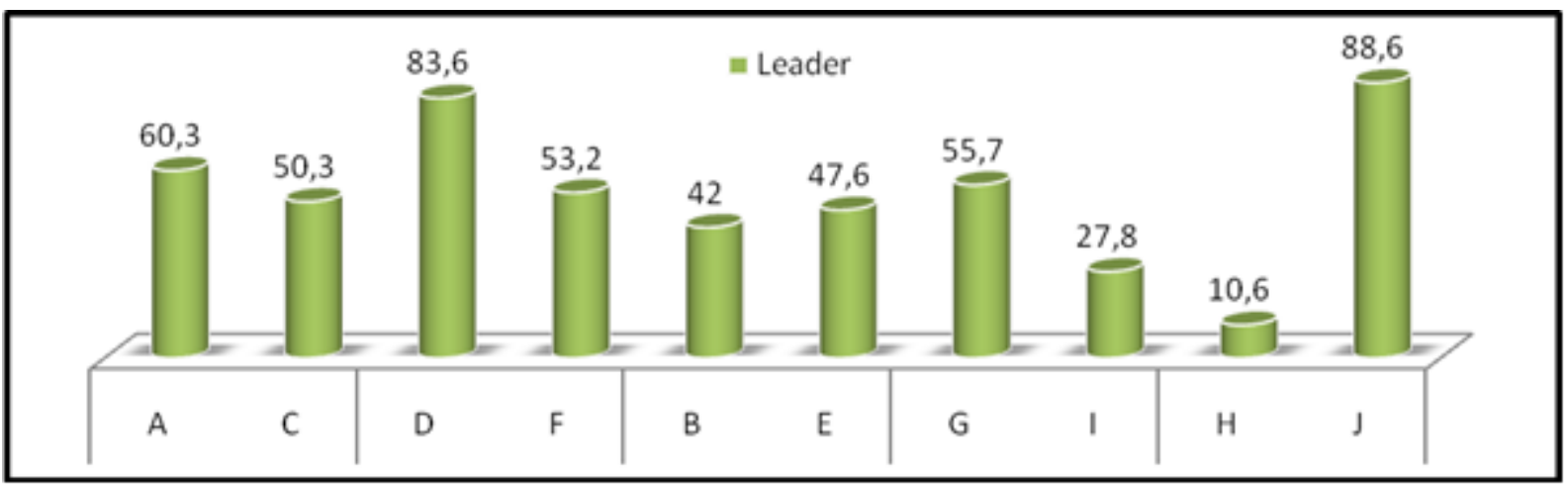

Figure 3: Results of the selection of skills in building the profile of the coach after the leaders

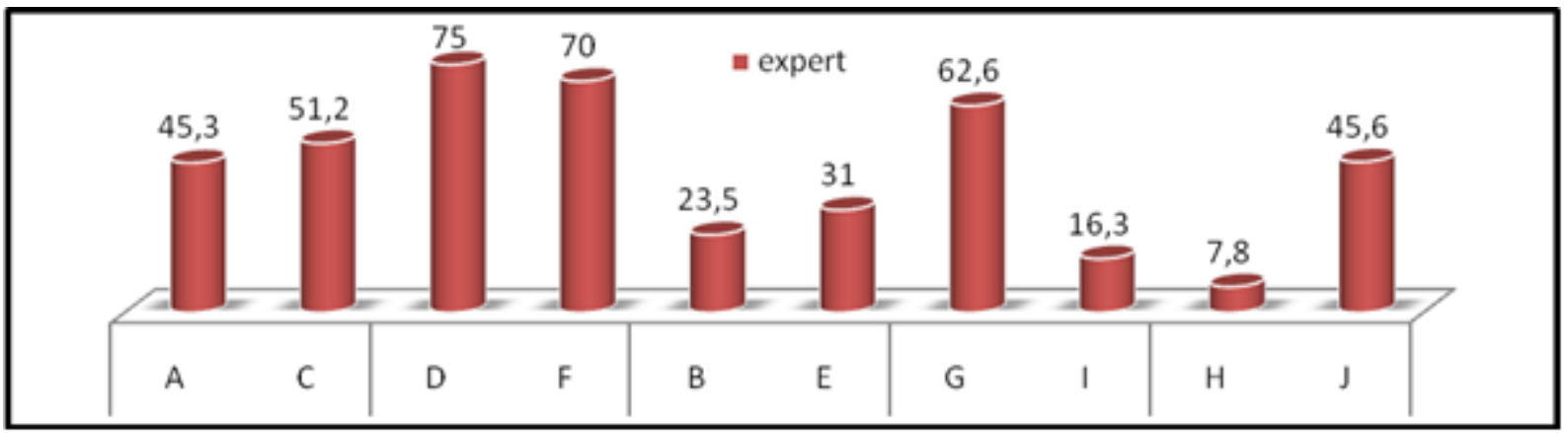

Figure 4: Results of choice analysis skills in building the profile of the coach according to Experts

Test application of Chi-squared:

Comparison of choices / non choice for each skill: 
The test CHI.2 allows us to answer the question on differences in choice of Athletes / Coaches / Managers / Specialists, highlighted in the previous charts, are they significant?

\section{Technical Skills:}

Item A: CHI.2: 5.29.indiquant a non significant difference between these 4 categories, for 3 degrees of freedom; at p.05 threshold (p.05 threshold = 7.81) .However, the comparison AT / ENT gives a value of 4.80 CHI.2, indicating a significant difference between the two categories (p.05 threshold $=3.84$ per 1 degree Freedom) .the athletes value less the skill coaches.

Item C: CHI.2: 3.33 indicating no significant difference between these 3 categories, for 2 degrees of freedom; at p.05 threshold (p.05 threshold $=5.99)$.However, the difference observed between ENT and DIR is significant at (p.01) CHI.2: 3.34, p.01 threshold $=2.7$ for 1 degree of freedom). These results indicate a tendency for coaches to exploit this expertise as leaders.

\section{Educational Skills:}

Item D: CHI.2: 0.26. indicating no significant difference between these two categories, one for degrees of freedom; at p.05 threshold (p.05 threshold $=3.84$ ). The percentages of the responses of the four categories for this skill show an agreement of the various stakeholders on the importance of this skill: it is the most valued of all proposed items skill.

Item F: CHI.2: 3.45. indicating no significant difference between these 3 categories, for 2 degrees of freedom; at p.05 threshold (p.05 threshold $=5.99$ ).

\section{Relational Skills:}

Item B: CHI.2: 0.70. indicating no significant difference between these 3 categories, for 2 degrees of freedom; at p.05 threshold (p.05 threshold $=5.99$ ).

\section{Organizer and Manager Skills:}

Item G: CHI.2: 0.54. indicating a non significant difference between these 4 categories to 3 degrees of freedom; at p.05 threshold (p.05 threshold $=7.81$ ).

Item I: It should be noted that the organizer and management skills collect a very small percentage of choices in four categories. This result would indicate an agreement of different actors on the low valuation of that skill

\section{Managerial Skills:}

Item H: testing the CHI.2 cannot validly apply here given the low observed frequencies (less than 2) on the modality choice for three categories of actors.

as in the case of previous skills, there seems to be a rejection of this skill, a very important agreement between the different actors of the sport system .

Item J: CHI.2: 0.56 indicating no significant difference between these two categories, one for degrees of freedom; at p.05 threshold ( p.05 threshold = 3.84 ) .

\section{Analysis of the choice of priority skills / coach profile:}

Tech.skills:

Item B: analyze accurately the performance of athletes, know the technical solutions

Teaching. Skills:

Item D: varying the training situations and knowhow to adapt them if necessary.

Relational. Skills:

Item E: listening to athletes, seek out the knowledge and understanding them.

Organizer and Manager. Skills:

Item A: adopt strict principles of material organization and time management.

Managerial, Animation and managing a team. Skills:

Item C: generate knowledge and take into account the views of athletes prior to making important decisions for the team

The results: below are expressed in percentage of the observed frequencies after grouping responses from various categories of stakeholders on the terms 1 and 2 (both skills were identified as most important).

\section{The priority skills in the coach's profile:}


Table 1: Selection of priority skills in the coach's profile

\begin{tabular}{|c|c|c|c|c|c|}
\hline$\%$ & $\begin{array}{c}\text { TECHN } \\
\text {.SKILLS (B) }\end{array}$ & $\begin{array}{c}\text { PEDA.SKIL } \\
\text { LS(D) }\end{array}$ & $\begin{array}{c}\text { SKILLS.REL } \\
\text { AT (E) }\end{array}$ & $\begin{array}{c}\text { SKILLS.ORG/G } \\
\text { EST(A) }\end{array}$ & $\begin{array}{c}\text { SKILLS.MANA } \\
\text { G (C) }\end{array}$ \\
\hline Athletes & 41 & 39.6 & 58.2 & 19.2 & 41.6 \\
\hline coaches & 75 & 20.8 & 45.8 & 29 & 29 \\
\hline leadership & 52.8 & 17.6 & 52.8 & 29.4 & 47 \\
\hline experts & 46 & 30.6 & 23 & 15.2 & 38.5 \\
\hline
\end{tabular}

Test application of Chi-squared

\section{Comparison of top choices for each category:}

Technical competence (B):

CHI.2: 9.91 indicating a significant difference between these 4 categories to 3 degree of freedom at p.05 threshold (p.05 threshold = 7.81). It appears that the coaches group values this way of significantly higher competence than other groups. The largest difference is between the coaches (75\%) and athletes (41\%), making appear a disagreement between the two groups on the importance of the technical skills.

\section{Teaching skills (D):}

CHI.2: 3.16 indicating no significant difference between these two categories, for 1 degree of freedom, at p.05 threshold (p.05 threshold = 3.84). However, this difference is significant at p.01 (threshold $=2.70$ ). This result reflects a tendency for athletes to exploit this instructional skill coaches in profile coaches.

\section{Relational skills (E):}

CHI.2 1.38 indicating no significant difference between these 3 categories, for 2 degrees of freedom at p.05 threshold (p.05 threshold $=5.99$ ).

Organizer and management skills (A):

CHI.2: 1.94 indicating no significant difference between these 3 categories, for 2 degrees of freedom at p.05 threshold (p.05 threshold $=5.99$ ).

Managerial (C):

CHI.2: 1.69 indicating no significant difference between these 4 categories to 3 degree of freedom at p.05 threshold (p.05 threshold = 7.81).

Analysis of first choice: comparative representation:

The most significant differences are in comparison Athlete / Coach; they concern the technical and pedagogical skills.

The choice analysis for deemed most important skill:

The results below are expressed as percentages of the observed frequencies for the modality 1: competence considered the most important of the five proposed items.

The most important skill in the coach's profile:

Table 2: Selection of the skills deemed most important in the coach's profile

\begin{tabular}{|l|c|c|c|c|c|}
\hline \multicolumn{1}{|c|}{$\%$} & $\begin{array}{c}\text { Tech. } \\
\text { skills (B) }\end{array}$ & $\begin{array}{c}\text { PEDA. } \\
\text { skills(D) }\end{array}$ & $\begin{array}{c}\text { RELAT. } \\
\text { skills (E) }\end{array}$ & $\begin{array}{c}\text { ORG/GEST } \\
\text { skills (A) }\end{array}$ & $\begin{array}{c}\text { MANAG } \\
\text { skills. (C) }\end{array}$ \\
\hline Athletes & 25.2 & 19.9 & 31.8 & 7.3 & 15.9 \\
\hline Coaches & 45.8 & 0 & 33.33 & 20.8 & 0 \\
\hline leadership & 47.1 & 5.9 & 11.8 & 17.6 & 17.6 \\
\hline specialists & 46.2 & 0 & 7.7 & 7.7 & 15.4 \\
\hline
\end{tabular}




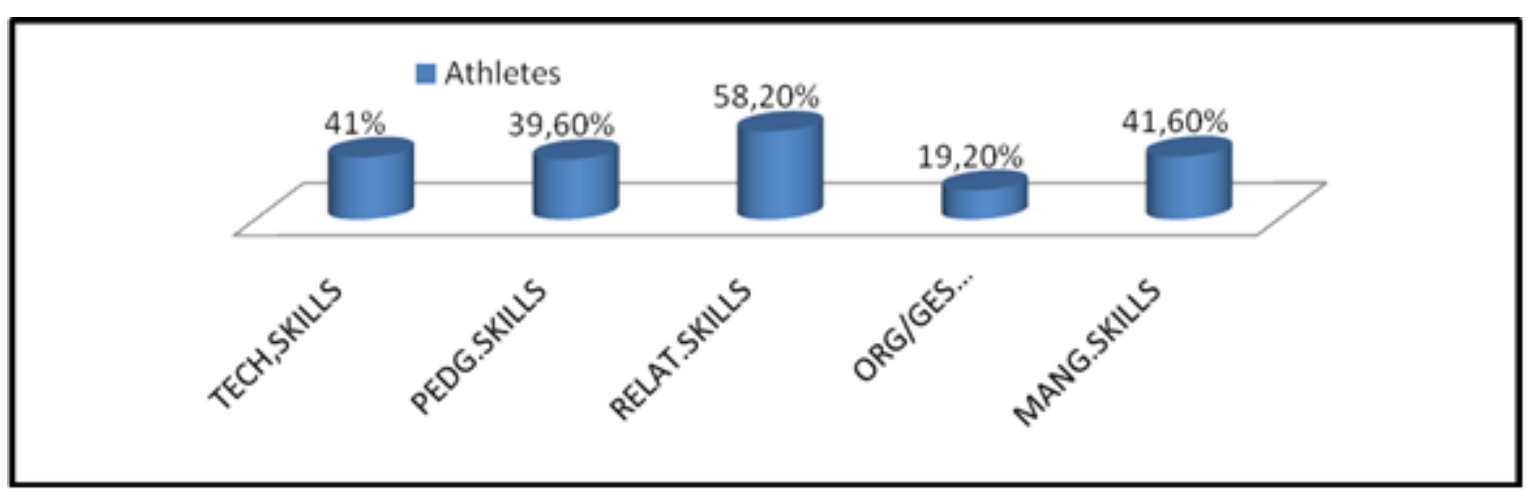

Figure 5: Results of choice analysis of the priority skills in the coach's profile according to Athletes

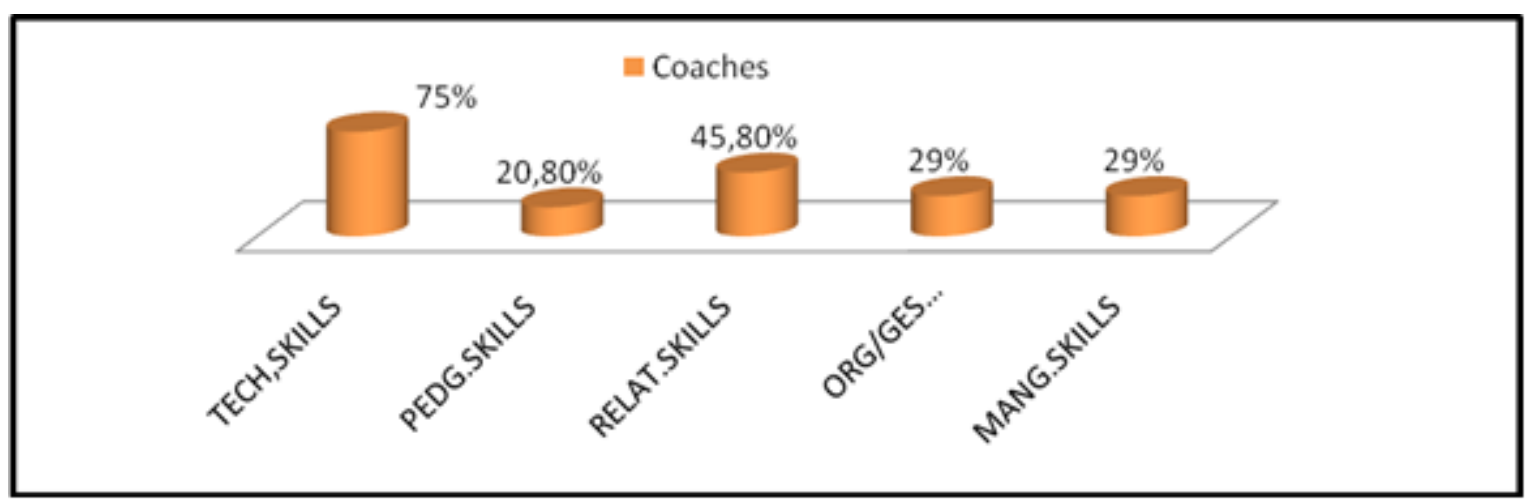

Figure 6: Results of choice analysis of the priority skills in the coach's profile according to the coaches

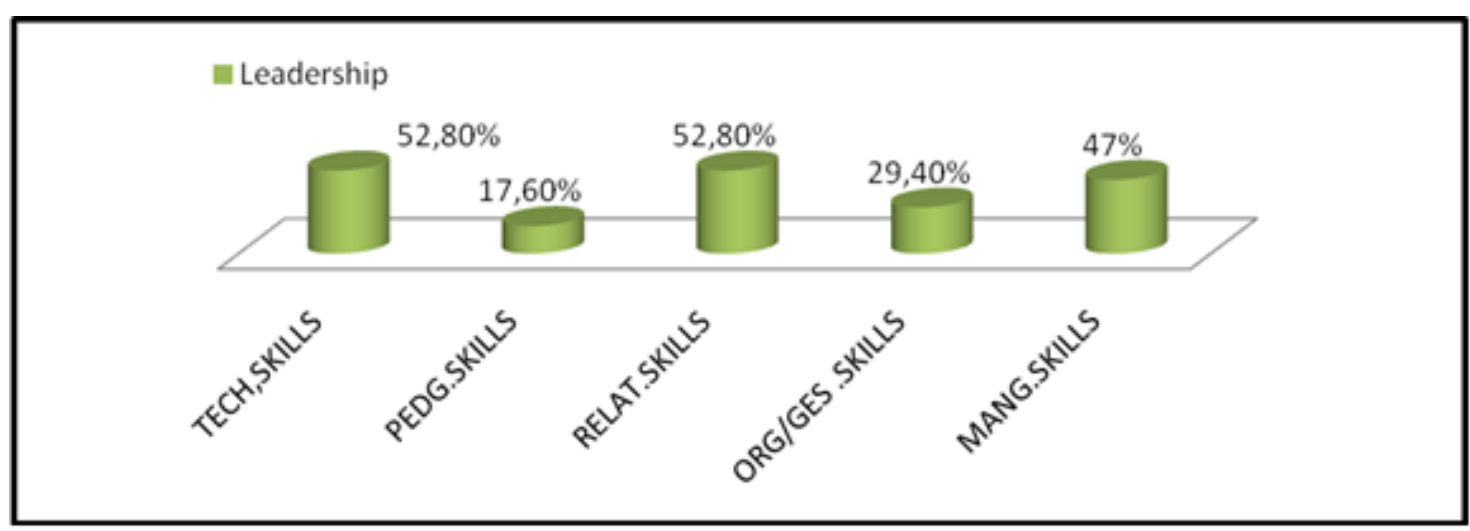

Figure 7: Results of choice analysis of the priority skills in the coach's profile according to leaders

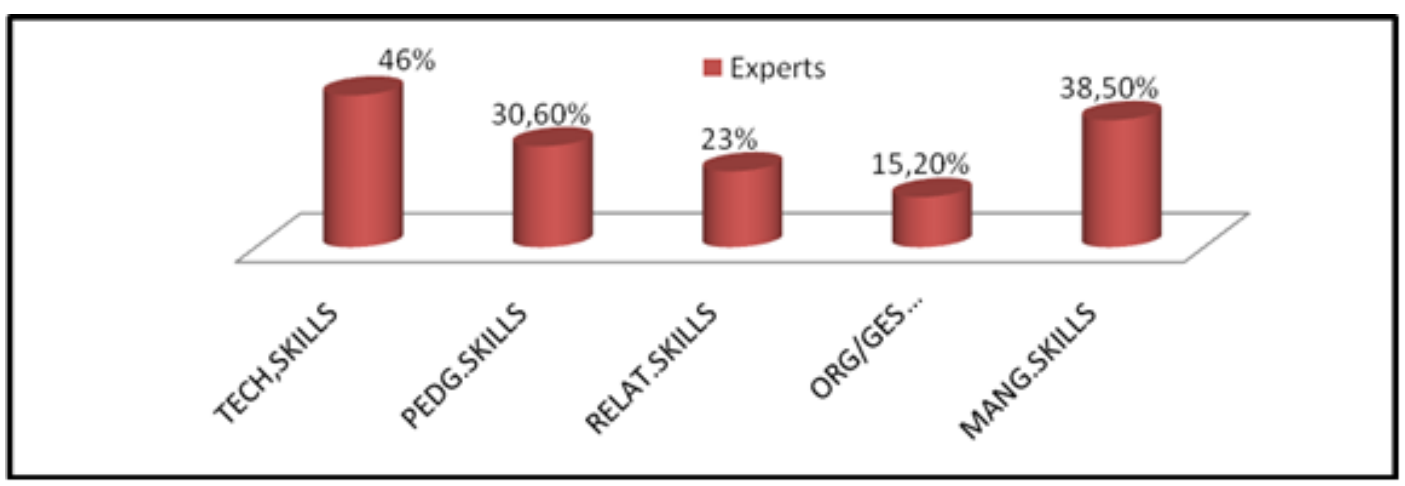

Figure 8: Results of choice analysis of the priority skills in the coach's profile according to the Experts 


\section{Test application of CHI.2 comparison of top choices for each category: \\ Technical competence (B):}

CHI.2: 4.38 indicates a significant difference between these two categories, for 1 degree of freedom, at p.05 threshold (p.05 threshold $=3.84$ ). This seems to confirm the fact that the coaches of group value the technical skills of significantly higher comparing to the athletes.

\section{Teaching skills (D):}

The test has no interest in this comparison because no coach has chosen this skill as competence 1, unlike athletes, including $19.9 \%$ rank this skill as the most important of the five proposed items.

This reinforces the idea of a disagreement between athletes and coaches on the importance of the teaching skills of the coach in the profile.

\section{Relational competence (E):}

CHI.2: 2.27 indicating no significant difference between these two categories, for 1 degree of freedom, at p.05 threshold (p.05 threshold $=3.84$ ).

\section{Organizer and management skills (A):}

CHI.2: 5.19 indicating a significant difference between these two categories, for 1 degree of freedom, at p.05 threshold (p.05 threshold $=3.84$ ) $.20 \%$ of coaches feel that this skill is the most important of the five items proposed.

\section{Managerial skills (C):}

As for the skill D, CHI.2 test has no interest in this comparison because no coaches selected this skill as competence 1 , unlike athletes, $16 \%$ ranked this competence as the most important of the five suggested items.

\section{Analysis of the skills' choices $n^{\circ}$ 1: Comparative representation:}

The most significant differences are in comparison ATH / COA, and concerning the technical and pedagogical skills.

\section{Conclusion}

The points of convergence and divergence between the various actors: We will analyze here, mainly, similarities and differences between athletes and coaches who are the most numerous and which maintain the most important relationships groups.

Consensus: the coach, "Field Specialist" (Leveque, 1992), in direct contact with athletes.

There seems to be a broad consensus among athletes and coaches in the valuation of certain skills and tasks. For example, it is essential for a majority of the population study that the coach is a reliable "outsider" and "target ", able to observe and analyze in performance (Hameline, 1979). There must be also a good teacher, able to animate the sessions, interesting trainings, explains and clearly conveys his analysis by showing methods, rigor in the organization and running of these sessions (Cotteaux, 1997). Finally, it is widely expected that it is equitable with all members of the team (Boterf G., 2000), understanding and listening to the athletes. The tasks that are considered to be the most important reinforce the contours of this competency profile (JOHSUA S. 1994). It is, overwhelmingly, the tasks of designing and conducting trainings (Bourdeault, 2005).

However, it appears according to the results, less important than the coach who has high skills in the areas of management (Lévy-Leboyer, 1997), organizational or management or that perform tasks accounting or institutional relations (Jolis, 1997).

It is not surprising that this agreement amounted to a "classical" representation of the coach: an expert and educator technician performing land business, in direct contact with athletes and focused on performance optimization sportsmen.

However, a closer analysis of the results also appears significant differences between athletes and coaches. Technician / educator: a disagreement between athletes and coaches (Parrington, 1988).

Coaches value more than the athletes technical knowledge (CHAUVIER 1988). It seems the most important example for coaches and athletes; the coach knows assay the training at the optimum level, or that he knows "the advanced technical solutions."

Conversely, such as skills, varied training situations (Boterf G., 2004), adapted to the level of athletes situations and external conditions, as is the ability to individualize the training are more valued by athletes rather than by coaches (Gasparini, 1996). 
This disagreement is confirmed at the level of the coach tasks (Delbos G. \& P. Jorion, 1985). Athletes favour trainings, driving tasks, whereas the coaches give the highest importance to the design tasks. In short, beyond the consensus, it seems that the coaches feel that they must, first, be experts and technicians (Lichtenberger, 2003), as athletes especially await as good pedagogues (without underestimating the technical skills).

\section{References:}

1. $\quad$ BOSC. (1983). approche psychosociologique de la relation entraineur-entrainé dans les équipes sportives in THOMAS La relation au sein des APS. Paris: vigot.

2. $\quad$ Bourdeault, H. (2005). Le savoir-être, un référentiel professionnel d'excellence Alain Labruffe. Paris: Afnor.

3. Bruant(G). (1989). les savoirs de l'entraineur, élément d'épistémologie de l'homme de terrain. Paris: A.F.R.A.P.S-STAPS.

4. $\quad$ Cardinet, J. (1988). Evaluation scolaire et pratique. Bruxelles: De Boeck.

5. CHAUVIER, R. (1988). l'entraineur et les phénomènes de relations, Mémonto de l'éducateur sportif deuxième degré. Paris: I N S E P.

6. Cotteaux, v. (1997). Analyse de la construction de l'expertise des entraîneurs d'athlètes de haut niveau. Perspectives pour la conception des formations de cadres sportifs. Paris: Mémoire pour le diplôme de l'INSEP.

7. Danvers, F. (1992). 700 mots-clefs de l'éducation. Paris: Métiers et pratiques de formation.

8. G. Delbos \& P. Jorion. (1985). La Transmission des savoirs, L'Homme, 1985. vol. 25, $n$ 96, pp. 151-153.

9. Gasparini, W. (1996). Thèse de doctorat: Sociologie. Enjeux de l'engagement associatif, Contribution à une sociologie de l'organisation sportive locale. Strasbourg 2: n 96STR20006. Paris: ESF.

10. Gillet, P. (1991). Construire la formation: outils pour les enseignant et les formateurs.

11. Hameline, D. (1979). Les objectifs pédagogiques. En formation initiale et en formation. Paris: entreprise moderne d'edition.

12. HELAL. (1986). téchnologie de la preparation sportive 'Mémonto de l'éducateur sportif deuxiéme degré I N S E P. Paris: Mémonto de l'éducateur sportif.

13. JOHSUA. (1996). Au-delà des didactiques, le didactique, le concept de transposition didactique n'est-il propre qu'aux mathématiques ? Paris, Bruxelles. De Boeck Université, 61-73.

14. Johsua, S. (1994). La Didactique des Sciences et des Mathématiques : une praxéologie ouun modèle théorique? Aix-en-Provence.

15. JOHSUA, S. (1994). La place de la technologie dans l'enseignement général et les recherches actuelles sur son enseignement. France: INRP, Lyon (FRA).

16. Jolis, N. (1997). Piloter les compétences: de la logique de poste à l'atout-compétence. Paris: d'Organisation Réflexion sur l'origine du concept de compétence et son impact sur l'organisation.

17. Le Boterf, G. (2000). L’ingénierie des compétences. paris: Edition d'organisation.

18. Le Boterf, G. (2004). Construire les compétences individuelles et collectives: les réponses à 90 questions. Paris: Éditions d'Organisation.

19. LEVEQUE, M. (1992). La relation entraineur-entrainé, perspective clinique sur sa dynamique affective. Paris: Science et motricité $\mathrm{n} 17$.

20. Lévy-Leboyer. (1997). La gestion des compétences. Paris: Editions d'Organisation.

21. Lichtenberger, Y. (2003). Compétence, compétences, in J. Allouche (éd.), Encyclopédie des Ressources Humaines, Paris: Vuibert.

22. Malglaive, G. (1990). Enseigner à des adultes. Paris: P.U.F.

23. Mialaret, G. (1979). le vocabulaire de l'éducation. Paris: P U F.

24. Parlebas Pierre, C. B. (1992). Statistique appliquée aux activités physiques et sportives. paris: Broché.

25. PARTIGNTON. (1988). «Devenir un entraineur complet». Revue science du sport, 60.

26. PIERON, M. (1992). Pédagogie des APS. Paris: édition revue EPS.

27. PLATONOV. (1988). L'entrainement sportif, théorie et méthodologie. Paris: Edition revu EP. 
28. RAGNI, P. (1996). la relation entraineur-entrainé en athlétisme: une demande d'amour à transférer à la technique.

29. Salmela John H., D.-B. N. (1994). La détection des talents ou le développement de l'expertise en sport. In: Enfance. Tome $47 n^{\circ} 2-3,233-245$.

30. WEINECK. (1990). Manuel de l'entrainement. Paris: Vigot.

31. Wittorski, R. (2008). Formation, travail et professionnalisation. Paris: L'Harmattan. Monde.

32. Zarifian, P. (1995). Le modèle de la compétence: une démarche inachevée. paris: Le

33. Zarifian, P. (2001). Le modèle de la compétence-Trajectoire historique, enjeux actuels et propositions. Paris: Editions Liaisons. 